\title{
Diversified quality production revisited: its contribution to German socio-economic performance over time
}

\author{
Arndt Sorge $^{1, *}$ and Wolfgang Streeck ${ }^{2}$ \\ ${ }^{1}$ University of Potsdam, Germany; ${ }^{2}$ Max-Planck-Institute for the Study of Societies, Cologne, \\ Germany
}

*Correspondence: arsorge@uni-potsdam.de

\begin{abstract}
We revisit the concept of Diversified Quality Production (DQP), which we introduced about 30 years ago. Our purpose is to examine the extent to which the concept can still be considered tenable for describing and explaining the development of the interaction between the political economy and concepts of production, notably in Germany. First, we show why and in which ways DQP was more heterogeneous than we had originally understood. Then, on the basis of evidence with respect to political, business, and economic changes in Germany, we show that DQP Mark I, a regime by and large characteristic of the 1980s, turned into DQP Mark II. In the process, major 'complementarities' disappeared between the late 1980s and nowmainly the complementarity between production modes on the one hand and industrial relations and economic regulation on the other. While the latter exhibit greater change, business strategies and production organization show more continuity, which helps explain how Germany maintained economic performance after the mid-2000s, more than other countries in Europe. Conceptually, our most important result is that the complementarities emphasized in political economy are historically relative and limited, so that they should not be postulated as stable configurations.
\end{abstract}

Key words: production concepts, manufacturing, diversified quality production, industrial organization, industrial relations, industrial restructuring, globalization, skills, Germany

JEL classification: M1, J5, P5

\section{Introduction}

About 30 years ago, we started thinking and writing about a concept of Diversified Quality Production (DQP) to express that larger companies counteract the bureaucratic drift to become more rigid within creasing personnel size, and that they could deviate from a Taylorist 
and/or Fordist strategy of standardizing products, emphasizing above all economies of scale and competing on lower costs and prices. We addressed what we saw as a deficiency in work sociology and industrial relations concepts of the time, which was also of increasing empirical relevance. We pointed out that such a DQP strategy was not only dependent on the volition of individual enterprises but rooted in an array of institutions in a society. Such an array of institutions enabled and instigated actors to pursue the strategy, so that it became both more feasible at the level of an enterprise and more prevalent in a socio-economy. We argued that Germany was an exemplary case of this happening.

Interestingly enough, while this interpretation and picture was generally well received, we started to have qualms about whether it was exact and sustainable. After about 1990, more and more studies by other scholars doubted whether a picture of DQP was still prevalent for Germany and could explain its industrial success after about 1990. This discussion is the occasion to review what happened to DQP in Germany.

We begin by restating the original concept and putting it into the perspective of the socio-economic context of the time. We then show which caveats, refinements and relativization we had added, based on our own research. Notably our reinterpretation of DQP in Germany had been disregarded by political economy students, concerned as it was with the details of work organization, human resources and industrial structures that political economists have by-passed. In the section of the article then following, we give attention to the changes in the socio-economic context, more generally but above all in Germany. We discuss the changes and their implication for the modality and the prevalence of DQP. In the section after this one, we state the current picture as it presents itself, bearing in mind the changes that have taken place. In conclusion, we argue that DQP has indeed changed substantially but that we had helped to deal with changes by moving towards a more refined statement.

The main argument here is that changes exhibit above all a decoupling of the array of institutions that we had considered as complementary to DQP operations practices. The operations practices appear to have changed less substantially and to have been renovated, so that they lost less salience than is sometimes implied. But we also see the persistence of an institutional bedrock, as background institutions rather than the more specific proximate institutions, as founding the renovation of DQP. More generally, we argue that a more dialectical perspective is needed to take the place of the more static argument about the explanatory value of complementarities, which appear to lose their pertinence in comparative socio-economics and political economy. This perspective builds on a better analysis and appreciation of a series of shocks to the functioning of capitalism; the shocks are specific for periods of capitalist development, and they are dealt with in ways again specific for socio-economies.

\section{The original argument about DQP}

DQP was conceptualized in comparative studies about what were then called 'production systems', now value creation systems, and about socio-economic settings interacting with value creation systems. At the beginning there was a debate in the 1980s, about 'effects' of 'new technology' - mainly microelectronic circuits of increasing density—on the kinds of occupational competencies required and their distribution, national industrial strengths, factor productivities and a great deal of other factors. Now, it is difficult to imagine the fascination with 'technological determinism' and the widespread fear that microelectronics would turn lots of things upside down, annihilate whole industries and sectors of employment but also 
potentially create new opportunities. In comparative investigations in Britain and Germany, Sorge et al. (1983) showed, for the application of computer numerically controlled (CNC) machine-tools as the major application of microelectronics in industrial processes, that 'effects' were a consequence of manufacturing policies and the embeddedness in socioeconomic institutions. Manufacturing policies depended on mainly two things familiar from studies of organization and technology: the routineness ${ }^{1}$ of value creation arrangements-technical, socio-organizational and related to the generation and use of human resources-and the size of value creation establishments, increasing size being linked with greater bureaucratic control and greater division of labour between laterally or vertically segmented jobs or occupations. The general result and argument was that 'effects' of new technology depended on its specific design and rationale of use, under the influence of changing policies to respond to market changes, and very much influenced by socio-economic settings subject to institutional continuity. Routineness was measured by the typical batch size in an establishment, i.e. the number of identical pieces produced one after another in a production run. Establishment size was measured by the number of people employed on the site. This turned the discussion of 'effects' of technology upside down, as can be seen, and it focussed attention on business and socio-economic policies and settings.

One of the value creation logics defined by the dichotomized factors of batch size (routineness) and establishment (or plant) size (Figure 1) conceptualized by Sorge and Streeck (1988) was diversified quality production. The idea was that more than often acknowledged in an age still marked by theories constructed during Fordism and Talorism, establishments that were far from small could also implement non-routine value creation policies, and were increasingly doing so. 'Diversification' of products and product pieces referred to non-routineness, whereas 'quality' referred to the fact that products were sold on quality, i.e. the use-value rooted in durability and reliability, on their contribution to capital productivity on the part of the buyer and user, or any other intrinsic value of the product down to the symbolic and statusenhancing value of a brand. Although we did not mention it at the time, there was a link with the business strategy concepts of 'differentiation' and 'cost leadership' introduced by Michael Porter (1980). Diversification was related to what Porter termed differentiation, and cost leadership to the opposite of quality, striving for cost reduction by going for economies of scale due to standardization of products or services. Our notion of diversification is distinctive for implying changeability and variability of value creation processes in one and the same establishment, and in this respect it has been different from the business and management meaning of the term. ${ }^{2}$ Product and process innovation could be part of DQP, although not emphatically and more in the form of incremental rather than radical innovation; the latter would have

1 'Routineness' stands for the dimension 'few exceptions versus many exceptions' as conceptualized by Perrow (1970, p. 83).

2 In the business and management literature, diversification means diverse products and their respectively different value creation processes, whereas 'our' diversification means customized value creation in such a way that diversity is handled in the same organized unit and process. This is therefore different from how authors such as Richard Rumelt used the term. 'Our' diversification is closer to the Porterian notion of differentiation which means that a product (range) is differentiated from that of competitors in a market, and possibly but not necessarily more customized, i.e. designed and made to more specific demand of buyers or buyer groups. The confusion between the terms was such that one of the present authors, who for a long time was a teacher in business administration, may subconsciously have repelled the term 'diversification' and used 'differentiation'. 


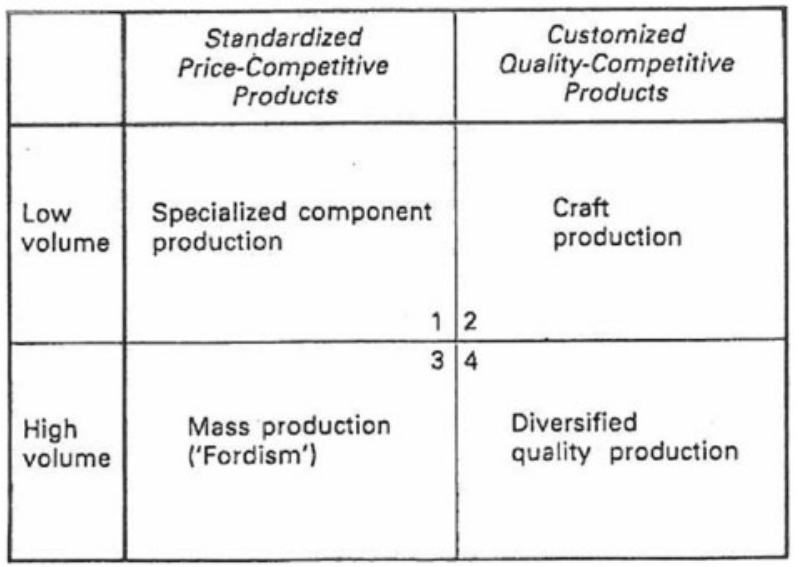

Figure 1. A simple classification of product strategies.

Source: Sorge and Streeck (1988, p. 30).

replaced products and processes with new one based on different competencies, so that diversification would not have been associated with it.

Admittedly, we conflated quality and diversification on the same dimension, whereas they could be looked at as different dimensions, in a more refined perspective. Even more dimensions of both quality and diversification could have been distinguished, and undoubtedly would have to have been added after more detailed consideration and research. But at a time when making a powerful counterpoint to value creation logics marked by Taylorism and Fordism was required, this may have been understandable.

The influence of generic enterprise strategies, however, was not the only and not even the most important thing. For value creation concepts were rooted, as the international comparison showed, in institutional socio-economic characteristics, and not only of an enterprise but the wider society in which it was embedded. There were long-running institutional conditions in a society, which facilitated DQP, as a strategy of enterprises or establishments. This shifted the attention to such wider institutional settings, and the argument was fully developed in Streeck (1991). The basic idea leading to an array of institutions was that DQP required the generation and provision of 'redundant capacities', and this followed on from an earlier and classical idea in the theory of sociotechnical systems, that diversification and customization of products and services for market segments attentive to quality and customization, notably in more changeable task environments, needed a surplus of competencies because the uncertainty of existing and evolving demand made a precise prediction of competencies needed impossible; providing competencies at precisely the level seen to be required so far, risked underequipment in competencies and, therefore, entrepreneurial and technical overspecialization and rigidity (Trist, 1981).

Provision of redundant capacities was then explained to require the following conditions in, not only enterprise-specific but wider societal institutions (see Streeck, 1991, pp. 37-42):

- Vocational education and training broadly based and geared to a high level, even and notably at the relatively 'lower' competence levels. 


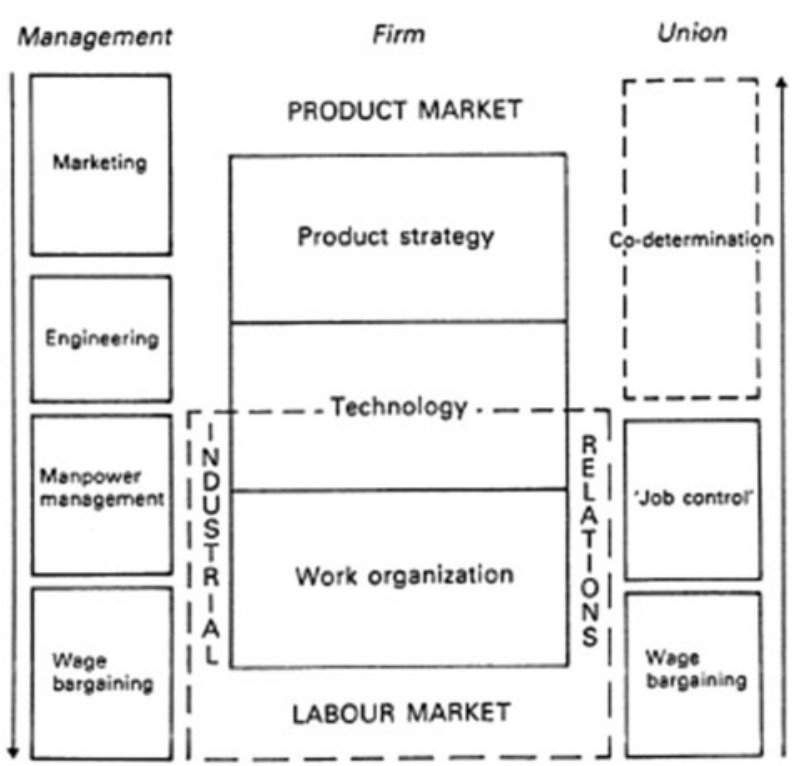

Figure 2. Technology and industrial relations in context.

Source: Sorge and Streeck (1988, p. 39).

- Organizational structures facilitating polyvalence, through overlapping and enriched work roles and functions, or departments, occupations and jobs, based on the design principle of interpenetration rather than segmentation.

- Decentralization of authority and competence.

- Social peace between management and workers but also different sections of the work force.

Such productive resources highlighted the importance of a societal institutional order (Streeck, 1991, pp. 42-45), were the result of collective processes beyond the reach of individual actors-individuals and enterprises. While individual actors, including enterprises could of course, provided the necessary insights and resources, ultimately install any value creation system they aspired to, a wider population of such systems was only conceivable if it was supported by dominant institutions in society (see Figure 2). This was later extended to a more general argument about the merits of 'collective constraints'-rather than individualization-with regard to industrial relations, vocational education and training, innovation activities and even entrepreneurship. However, the argument was not purely socialist but based on a corporatist regime involving the state, employers and trade unions in interrelated and jointly governed activities establishing institutional norms and procedures limiting and channelling social conflict within a regime of Konfliktpartnerschaft, a term difficult to translate $^{3}$ because it implies 'partnership in conflict', such that peace results from the

3 One of us recalls an interview in 1993 with Pascale Hugues, at the time correspondent of the French daily Libération in Berlin, when she asked if, with a larger metalworkers' strike in Germany just after unification, peace was coming to an end. The reply, that this was a perfectly normal event within a 
ordered exercise of conflict, in a lengthy process of path-dependent institutional creation that makes the opposition between peace and conflict dialectically congeal into interdependency.

Focussing on the example of (West) Germany, Streeck (1991, pp. 52-54) pointed out that the core institutions embedding DQP as a more likely response in society were:

(1) a system of 'rigid' wage determination, establishing more equal wage levels and procedures in an industry;

(2) a system of employment protection based on legislation and collective agreements;

(3) 'a set of binding rules that obliges employers to consult with their workforces'-codetermination in boards and of works councils and other bodies;

(4) a training regime creating an oversupply of more broadly trained workers-redundancy of capacities at industrial levels, a quasi-reserve army of workers but deprived of the more dismal Marxian connotations;

(5) a system of rules regarding the organization of work (in agreements, professional standards and programmes such as the Humanization of Work programme in West Germany) facilitating flexible use of workers-redundancy of competencies as a design principle in establishments.

Note that institutions working towards DQP did not figure as purely external to the enterprise but embraced both, enterprise practice and more 'macro' regulation. The idea was that 'West German institutional constraints and opportunities seem to form an interactive pattern of mutual reinforcement and causation, .... a virtuous circle of upmarket restructuring' (Streeck, 1991, p. 54). We had also conceived of this interactive pattern as one of 'elective affinities' (Wahlverwandtschaften), such that institutions as mentioned above, from product and work design policies in separate establishments up to macro-regulated norms and standards, would over time 'find each other' and come to be associated with function and meaning. ${ }^{4}$ The later political economy literature came to look at such elective affinities as 'complementarities' but often in a more static view emphasizing that emphasized a functional coupling, such that presumably a change on one dimension would imply a change in the others. Another source of the 'interactive pattern' was the concept, in the 'societal analysis' approach within which one of us has worked for a long time, of a fundamental and inevitable interaction across societal 'spaces' (or organizing, human resource construction, industrial relations, etc., see Maurice and Sorge, 2000). However, different from the political economy contributions that used 'complementarities', there was not the idea that specific institutions became and were necessarily tightly coupled. They could be 'uncoupled' without putting the intense interaction between spaces into question, such that the interaction also facilitated institutional change of a more unsettling kind. Our original concept could be seen to suggest that elective affinities or complementarities would imply institutional change 'in step', as it were, a change in one of the last-mentioned characteristics always being linked with a change in all the other characteristics, in the same direction and at the same pace. The

consistent pattern of Konfliktpartnerschaft, left her looking baffled, trying to grasp the meaning of the word.

4 This could be imagined to occur much as in the classical novel by J. W. Goethe: People that were related by more than kinship find each other and coalesce. 
puzzling possibility of 'decoupling' was not one we had considered at the time but it turned out to be important, as we shall see.

There were a number of connotations implied in the earlier papers which need to be highlighted more than they were at the time, by a historical contextualization of the papers with regard to the socio-economic changes that had happened before the time of writing. With the suspension of the gold standard of the Dollar by President Nixon in 1971, and notably with the fluctuation oft the German Mark against other currencies after 1973, a phase of post-war reconstruction which French economists and media have come to call les trente glorieuses), ${ }^{5} 30$ years of economic boom governed by a Taylorist and Fordist accumulation regime, came to an end. Before the fall of fixed but also changeable currency parities, Germany had gained economically from comparatively less wage and price inflation leading with other factors to an increasing competitiveness of industrial firms and above-average growth rates. This was also a time of expanding mass production, in Germany no less than in most OECD countries. But through unequal and changing growth and notably inflation rates and trade balances in the OECD world, currencies became subject to appreciation (mainly Germany) and devaluation pressures; such pressures were aggravated by shifting and increasingly speculative 'Euro-Dollar' market forces. Whereas some countries (the USA, Britain, France, Italy) were driven to devalue their currencies and could thus to some extent compensate the effect of higher inflation on competitiveness, revaluations of the German Mark and flexible exchange rates after 1973 meant shocks to export industries. From textiles and garments via optical equipment (cameras and binoculars, among others, massproduced equipment in which Germany had had a world leadership), heavy industries such as steel-making and ship-building, down to a whole range of consumer goods, German firms in a short time became price-incompetitive despite restrained wage and price inflation. Contrary to many readings, enterprises in Germany have not been less sensitive to price and cost considerations 'by tradition' (Herrigel, 2015, p. 133); this tendency emerged only after a long time, with many set-backs, and initially, Germany had only gained a foothold in international markets by competing on price, just as Japan had in the 1960s.

New industrial countries emerged, mainly in Asia but also in other parts of the world, such that what is often called deindustrialization is in fact the deindustrialization of the OECD world but also the industrialization of the third world, a counterpoint often forgotten. For Germany, an export leader already in the 1960s, the exchange rate flexibilization for a time meant concurrent upwards valuation of the Deutschmark and the resulting price pressures that mainly affected price-competitive and mass-produced goods but also shipbuilding, which had not been a mass production industry. Without any doubt, the resulting structural problems were at least as serious in Germany as in other OECD countries. It was not immediately predictable that restructuring, of industries and of capital and labour policies, in Germany would be more alert than elsewhere. But it did turn out to be so. Restructuring problems had marked the period which informed our studies and analysis, with empirical work mainly in the second half of the 1970s and the beginning of the 1980s, the period in which the initial and fundamental effects of the shock had happened.

5 The years were not wholly glorious, especially not for France which suffered until nearly 1960 from an economically and politically debilitating war in Algeria, which was a drag on reconstruction, as was the colonial war in Indochina. 
In industrial structure and in enterprises, the effect showed in a changeover to DQP where innovation, production and marketing strategies were concerned, and they were in a clear relation to revival of a longer-lasting institutional bedrock. DQP stood out at the time, by performing a break with a Taylorist and Fordist past, and in companies, and the rationale for DQP was unambiguously stated by managers: More standardized mass markets were more competitively catered for by competitors in other countries, more demand could be captured by shortening a product life cycle, ${ }^{6}$ and there were greater profit margins to be reaped when products were customized; on top of that, growing productivity combined with growing production variability implied an intolerable increase in working capital (stocks and stores, inputs and spare parts), if not checked by further increasing production variability to reduce working capital and work-in-progress, also shortening throughput times (Sorge et al., 1983). This was the sum total of industrial upgrading prevalent at the time, and it was reflected in the industrial restructuring in industries and in enterprises, researched and shown e.g. in an Anglo-German comparison of several industries by Cox and Kriegbaum (1980). All the evidence pointed to the fact that West Germany came particularly well through the period of restructuring following the collapse of the Bretton Woods regime of fixed exchange rates, by the upgrading and further development of products, which went in the direction of greater diversity and customization.

Now, the industrial change appeared singularly conducive to, and dependent on, precisely the socio-economic institutions mentioned above, so that we had the syndrome of interacting factors inherent to DQP extending from changes in the international economic order down to policies in specific enterprises; furthermore, it all appeared to happen in such a way that value creation systems notably in West Germany came to match better the other institutions in the socio-economy. In comparison with other countries, these now seemed to have been tangential to, if not in conflict with, a situation of mass production. Hence also derived the argument that there are clearly phases and parts of capitalist development, in which 'collective constraints' imposed on the value creation process worked better for capitalist enterprises, than perfect short-term spot markets with participants operating on an individualistic basis. The argument was not that firms in a liberal market economy could not implement DQP, but they would incur greater costs, and actors from entrepreneurs through managers to workers and their representatives would not be led and enabled to do this to the same extent. Firms in such an economy would thus not be systematically tempted towards DQP by the institutions they operated under, and which they willingly or unwillingly helped to reproduce. This was also an argument in favour of the international division of labour being linked with, if not dependent on, the way the socio-economy was endowed with culture and institutions. While this argument was very general, DQP had to be seen as contextualized within a period of change away from value creation regimes predicated on expanding mass markets. In this period, DQP stuck out, which led to a stylized treatment of the evidence and meant a penchant to conflate dimensions and an emphasis on what were later called complementarities.

6 In the beginning of the 1980s, the shortening of product life cycles was discussed in the business literature as 'dematurity', evoking more demand by more product inovation. 


\section{A more complex picture of DQP in a socio-economy}

While our arguments were generally well and constructively received, notably in new research and theory about 'business systems' (Richard Whitley and others) and 'varieties of capitalism' (Richard Hall and David Soskice), we were also among the first to append critical reflections and countervailing evidence. One nagging question had been to what extent DQP, large as the concept had become over time, could validly characterize a whole socioeconomy. Could it have been that the salience of DQP in the later 1970s and earlier 1980s was subjective, as it had jumped into view after changes in the world economy post-Bretton Woods but may have been counteracted by other features and developments?

Industrial development has always had two sides. There have been alternating and conflicting waves, of the intensified and of the diversified use of the factors of production. Intensified use of human resources has been linked with the spread of 'best practices' such as the segmentation of work systems, Taylorism and Fordism. But on the other hand, we have also seen that there have been counterpoints to the spread of such practices, not only through what has come to be called 'hybridization', as universalized value creation and management recipes were assimilated to more local practices. Mass production and continuous process production have tended to require a type of production that appeared as just the opposite of the the type of value creation they supported. The most pronounced example is the inevitable link between routinization of work and automation (in large batch and mass production) on the one hand, and non-routine work and enriched work roles (under customization of products and services) on the other. Routinized and particularly automated production and mass production rely on highly customized development and production of dedicated machines. Thus, mass production of automobiles has required transfer lines and other machining systems for parts production-machine systems designed and manufactured to be specific to the requirements of users. For their specific adaptation to a manufacturing purpose was the major foundation of their economy of use. Hence emerged a population of makers of highly customized manufacturers of machine-tools, particularly in settings where mass production became widespread. At this point, it is important to reiterate the crucial difference between the machine-tool industry (and firms) on the one hand, and the wider machine-building (or mechanical engineering) industry and firms on the other: Machine-tool firms make machines that set tools to work on objects, to give them the shape required by a design drawing in the widest sense. Such machine-tools are used by firms in many industries, machine-building among others, to generate the precise shape and other characteristics required of parts. The two industries may have opposite organizational and human resource characteristics, and they must never be confused. ${ }^{7}$

A notable case in point is France which, especially during its trente glorieuses, developed populations of mass producers, but also the dedicated machine-tool manufacturers to match. The central implication is that socio-economic institutions are subject to countervailing pressures: One is to fit and to promote standardized products and services, and the other is to fit and to promote their exact opposite, customization. In view of this functional interdependency of opposite types of value creation, institutionalism has been confronted with a puzzle: How can we reconcile functional interdependency with institutional opposition and

7 Even specialist researchers such as Herrigel (2015, p 137) are guilty of spreading confusion about what the industries are. 
what happens in empirical fields, when functional interdependencies lead to conflicting institutional affinities, whereas institutions are supposed to be generalized to an important extent, over and above functional requirements? At the outset, there appeared to be a logical response to the challenge: Societies and economies will specialize, in the international division of labour, in the activities that match their generalized institutions.

In this way, DQP theory and underlying studies would have suggested that in view of its institutional and cultural setting, Germany should have had DQP manufacturers in machine-tools that were less routinized than the French firms in the industry, had more craft workers, and would have weathered the industrial crisis of the machine-tool industry after the end of the 1970s precisely for the reason that they were more 'hard-core' DQP, i.e. more geared to non-routinized manufacturing. This was the logic of our earlier thinking: The more you were DQP, the better you could withstand the shocks in the 1970s and evolve towards new product and services marked by customization. Furthermore, the German machine-tool industry had been considered by many students to be a hallmark of the opposite of work segmentation, Taylorism and Fordism. However, upon closer investigation, the opposite was the case on most counts: The French firms were more DQP in their product portfolio and for this reason, they came into much more serious difficulties during the crisis (Sorge and Maurice, 1990). What had happened?

It was the demise of highly routinized and automated manufacturing during the industrial crisis in European and North American countries, in the industries that bought machine-tools, which led to a turn to less dedicated but more flexible machines, using more flexibly programmable electronic controls. The Japanese machine-tool manufacturers responded to this change more quickly and systematically, becoming world leaders in universal but flexible machine-tools, made in large batches. The German machine-tool firms were less routinized, in an intermediate position between the Japanese and the French firms. They could hold their own in the crisis, by being less DQP than the French firms; the latter to a large extent went bankrupt or finished up under Japanese corporate control. However, the differences in national institutional and cultural settings still turned out to be important: More embedded in networks of research and development with technical universities, more prone to inter-firm cooperation, with occupations in production engineering that had higher status and intertwined the sophisticated and the mundane aspects of such occupations, and with bigger firms, and with more intensive experience in routinized production than the French competitors, they performed the switch to universal and flexible machine-tools more systematically. There were bankruptcies in the industry but also new firms that entered it, in Germany. This comparison showed that 'more DQP' is not necessarily better than 'less DQP', and in the industries supplying capital equipment to DQP manufacturers, the opposite was likely (see Sorge and Maurice, 1990 for details). This comparison was important for making the point that Germany, depending on the industry, also profited from being less DQP than firms in other countries. Nevertheless, the institutional argument about the importance of an supportive 'ecology' of firms, institutes and institutions still stood: This embeddedness was one of the advantages of the German firms, and it was, again, related to the argument about markets: The German machine-tool firms had also had more experience in the modularized manufacturing of universal rather than dedicated and highly customized machines. In addition, the greater institutional and cultural homogeneity in Germany, of occupations and work organization across branches of industry, with a greater similarity 
and affinity between the machine-making and the machine-using industries, was also helpful.

One can now see an important point emerge, modifying our earlier DQP concepts. German DQP was not important by any 'hard-core' quality, i.e. it was not a sharply focussed practice oblivious to economies of scale in batch production. It was the more general spread of DQP which meant that it could not be conceived in sharp distinction against large batch production. A sharp distinction was found in other countries, and this hampered the progress of DQP, rather than supporting it. The institutional isolation of DQP firms against mass producers, especially if industrial prestige and supporting institutions had previously gone to the mass producers, was apparently a central factor working against it. The situation in which DQP had emerged as salient may have led us, as we said above, to emphasize a sharp, coherent and distinct profile. But in fact it appears to be a concept distinctive for its internal variety and breadth, and the breadth implies that it has more variety with regard to routineness and batch production than we or our readers may have thought.

But not only the internal variety has to be re-appreciated, also the link with the argument about performance. In the more conventional theories of organization, 'contingency theory' means that firms perform by achieving a 'fit' between organizing and the task environment, such that e.g. the shift to more variable and less certain tasks, e.g. due to industrial restructuring and lack of demand for more mature products, go together with a shift to DQP. While this was not entirely wrong, we had to countenance that DQP, because of its breadth, was more dialectically 'bubbly' in the following way: German industry profited from a capacity to shift appreciably, from larger batches to small batches and the other way. It probably was the versatility in making such changes without running into difficulties, changing from one type of value creation competence to another and back, if needed. In organization theory, this is referred to, in a more stylized form, as 'ambidexterity', i.e. the ability to work with both hands equally well. In organizing, this means the ability to combine, and to shift between, divergent policies. In human resources, in a similar way, workers combine routinized activity with coping with unforeseen circumstances, practical experience with more abstract capacities, and manual work with a conceptual understanding.

In this form, the DQP argument still featured, and even more so than we had expounded, the institutional corollaries of broadly dominant institutions explained above. Institutions in a society are, after all, distinctive for promoting behaviour, whatever the precise commercial and economic logic prevalent at a place and time appears to be. Although institutions are eminently useful in a general way, and useful in particular ways depending on their precise characteristics, compliance with institutions by actors is always beyond utilitarian motives. This has been our reasoning from the outset. It is just that the link between institutionalized and utilitarian behaviour, being dialectical, makes a broad notion of DQP more 'bubbly' than in some versions of 'new' institutionalism, whereas 'old' institutionalism has had a truly dialectical concept of institutions. ${ }^{8}$ The latter is also present in historical institutionalism, such as in the treatment of American industrial capitalism and its institutional changes over time, by Hollingsworth (1991). In the same way, it can be shown that a German mode

8 In organization studies, old institutionalism stands for such authors as Selznick (1996) who saw institutional sets as inherently conflictual, making for conformity but also creative deviation from standards. New institutionalism was represented by authors such as DiMaggio and Powell (1991), who more single-mindedly looked at institutions as generative of 'isomorphism'. 
of production has not always been identical with quality manufacturing; 'Made in Germany' was an imprint enforced on German imports by the British government more than 100 years ago; it only acquired a quality connotation gradually, over time. It did, however, rest on a body of human resources recruited among apprenticed artisanal craftsmen and featuring engineers and technical managers with production training and experience. More routinized production of standardized goods stood at the beginning of German exports, and the 'quality' connotation became established much earlier than the strategy of customization and non-routine manufacturing. Again, it was the ability to shift from one to the other, and to combine them, that was central, resting as it did on broad bases of occupational competence and occupational and career linkages between the more academic and the practical (Sorge et al., 1989). DQP thus originated from the Q end and step by step shifted towards the $\mathrm{D}$ side; the most decisive step happened after the industrial transformation postBretton Woods had begun, with the deindustrialization of Europe and North America and the industrialization of the Third World.

Whereas it has become customary to highlight the contribution of Mittelstand (non-corporate or owner-managed) firms to German economic performance, more than in any other comparable larger country, such firms are often at the margin of DQP, which does not mean that it is doubtful if they belong in this category. Let us consider some examples. A brand probably very familiar to gardeners in many countries is Gardena. The firm originated in the post-war period and it became a leader in the design and manufacture of garden watering systems. In one way, this is a very commonplace product made in very large batches. But on the other hand, the attractiveness of the product resided in very handy and standardized couplings, with hoses, sprinklers, taps and other equipment. The couplings were made from plastics, which was a change from the brass couplings used earlier, but one that required an ingenious (patented) design and attention to the new production process for the couplings (injection moulding), to obtain the robustness and reliability expected by gardeners. This is definitely a quality product, not one made in small batches but mainly mass-produced. Many would ask why this kind of production has not moved to Italy, Spain or China long ago. It simply has not. In the meantime, the firm has also diversified its portfolio in the direction of more sophisticated watering systems, e.g. for botanical gardens and greenhouses or similarly demanding clients, adding computer control and sophisticated sensors. Here, non-routine development and production have definitely come in. But they have remained combined with facilities for the more staple parts of the product range. German DQP means their combination for as long as appears tenable, even as some relocation of plastics production to another country has occurred, and even as the company was integrated into a larger Swedish group.

Another model case would be Liebherr, a larger firm taditionally making refrigerators, but increasingly refrigerators for professional users, and cranes. Both the quality and non-routine connotations were further strengthened as the firm moved into aerospace, developing and making pressurization and climatization equipment for passenger aircraft. More recently, it has also begun making undercarriages for aircraft. Presently, the firm is not quite a rival for Plessey-Messier, an Anglo-French firm making the more sophisticated and heavy undercarriages for the aircraft industry. Some of its development in aerospace has been moved to Toulouse, to be part of the most decisive cluster in the European aircraft industry. Again, it is distinctive for German DQP to combine different production systems, levels of technology, quality and extents of customization. It is also suggestive to realize the history of Kuka, a leader in the development and manufacture of industrial robots for industrial production 
(welding, handling, assembling, etc.). While the non-technical public tends to associate this with high technology, spin-offs or start-ups close to research centres, for Kuka the history is quite different. The origin lies in the making of the hydraulic and pneumatic equipment that picks up dustbins, tilts them into the rubbish receptacle of the truck to empty the contents, and puts them back in a vertical position. To an engineer, such equipment is a kind of robot already, with clear requirements for the robustness and reliability of complex movements involving a number of levers connected by joints; it is just that there is no computer yet for the control of the axes and movements involved. Thus did the engineering mind and enterprise make the step from rubbish truck equipment to industrial robots. And in the meantime, the former operation has also learned from robot-making, leading to a more robotized equipment that also lifts the bin from the pavement, rather than requiring a loader.

The examples all make the point that the mundane and the sophisticated are combined and feed into one another, within a broader area of DQP that emphasizes quality in the first place and combines non-routine and routine aspects of manufacturing. Despite the diversity of different products and organizational subunits, there is an integrative element in all this, provided by the institutional bedrock in human resources, management and organization, and industrial relations. To this extent, DQP in Germany must be conceptualized as more comprehensive than its hard core, i.e. emphasizing quality more than extreme customization, and as excelling at the combination of routinized with non-routinized operations, and at switching from one to the other.

However, there is another caveat extended to DQP reasoning, which takes the international regulatory context into consideration, also implying regulatory changes in the domestic economy. Streeck (1991), also relying on work done some years earlier, suggested that the evolution of market orders and the upswing of international financial capitalism put DQP in jeopardy, mainly because the liberal international order was devoid of the productive collective constraints that enabled DQP. The argument was sharp, by suggesting that although DQP was, in a way, a superior mode of production in a socio-economy becoming 'post-Taylorist and post-Fordist', certainly for the more industrially developed world that had been relocating many routine industries into the 'third world'. The idea was thus that a financialist and capital market oriented governance of enterprises, issuing forth from the USA and supported by other liberal market economies, would institute a market order and management and organization routines that counteracted DQP. Streeck also suggested that the unification of Germany, which had happened just a year before the publication of the article, held out another challenge with unpredictable effects, given that the East German economy had, above all, concentrated enterprises with standardized products and services, selling more on price than on quality or customization. It is now often forgotten that e.g. furniture selling under the IKEA label and becoming wildly popular under the connotations of folksy and egalitarian Swedishness, was in fact mass-produced in East Germany, to some extent in a prison where labour costs were particularly low.

To sum up, the caveats which we had elaborated against a 'hard-core' view of DQP in Germany were the following:

- DQP in Germany is stronger on the quality dimension than on the customization dimension.

- It should be conceived as featuring shifts from large batch production to customization and vice versa, and as enabling combinations of these. 
- Its persistence and spread not only depended on business efficiency and effectiveness but dominant trends of economic governance and managerial culture at the international level.

\section{The instability and shifts of DQP over time: the structural shocks of unification, internationalization and neoliberal reforms}

In the period of roughly 10 years after 1990, Germany was unique not only in a comparison with other societies but also in a much more long-run perspective; while it was subject to internationalization under the auspices of liberal reforms and financialist governance, it had to perform the integration of a former socialist society of 16 million inhabitants that had gone bankrupt, economically and politically, into its own 'social market economy'. This event was unique in the social history within recent memory, and those who underwent it or looked at it, it was absolutely breath-taking. For it was not clear on the outset if and how this feat could be performed without severe disruptions to the 'normal' functioning of the socio-economy and violent conflict. The declared aim of unification-assimilation of institutions and economic structures and standards-into a relatively high-wage economy, from a centralized command economy overburdened by foreign debt and less than a fourth of the productivity of the economy East Germany was entering, was daunting.

In retrospect, what happened can be divided into a short-run effect and a long-run effect. As predicted by Streeck (1991), however, everything that happened called DQP and the set of institutions and standards linked with it, by elective affinity or complementarity, into doubt. Earlier, this set-DQP plus complementary institutions and standards-had been stylized as a 'German Model' for manifold political purposes, stretching from Social Democratic federal election campaigns to the memoirs of Helmut Kohl. Scholars have also used the 'German Model' in a loose way, accommodating many different and changeable characteristics. ${ }^{9}$ At the same time as unification happened, Germany was also like other countries subject to liberal reforms instigated from abroad, mainly the USA and the UK, and by supranational authorities such as the European Union and the World Trade Organization. This combination of a very national policy concern-unification-and the international concern with liberal reform is again unique, set as it was against the opening up and democratic revolution or reform in the former COMECON countries.

For Germany and with regard to DQP, there were in principle two different options of performing the changes, and the options were not mutually exclusive but permitted intermediate solutions and combinations. One option would have been a radical pursuit of everything implied in DQP and its suggested institutional affinities, to reap the economic benefits of structural change that were required for integrating a bankrupt former socialist economy into the socio-economy of the new Federal Republic. This would have boiled down to going for more quality in products, more customized operations, more qualitatively competitive rather price-competitive products, more concerted and co-managed industrial relations, allowing higher profit margins but also higher wages, and the concomitant economic growth. This would have been a DQP 'high road' to unification and growth. The other

9 One of us has jokingly said that there are many 'German models': Claudia Schiffer, Nadja Auermann, Heidi Klum, etc., and they are all different. This was to express that use of the term had become too encompassing and ambiguous. 
option was to swallow a 'bitter pill' inherent to massive socialist enterprise collapses and unemployment in East Germany, namely a move away from DQP and high wages, towards routinized large-scale operations systems, wage restraint or reduction, and a scaling-down of the socio-institutional apparatus of concertation and co-determination, generally applicable collective agreements and tax or social insurance based public benefits. A fast pace of assimilation of institutions and levels had, after all, been decided in the negotiation of the treaty of unification and all the decisions made by the government and the social partners. What was forgotten or neglected in the negotiation of the unification treaty and pursuant decisions was how the reach a level of productivity, profitability and public revenue to maintain public and private benefits, not only in East Germany but also in the integrated country.

Both of the options implied a maintenance of the elective affinities or complementarities inherent to our initial DQP approach; but the options pointed into radically different directions of development. On the 'high road' the DQP syndrome would have been intensified, and in the 'bitter pill' scenario DQP and its elective affinities would have been reversed into the direction of price-sensitive large-scale production.

Let us see what happened to DQP and what the evidence for complementarities and elective affinities is, over time. The most dismal period by all accounts is from 1992 until after the middle of the 1990s, when formerly 'socialist enterprises' were dissolved or carved up and scaled down radically, in the conversion to a market economy and private ownership. Increasing taxation (a supplement to the the income tax, Solidaritätszuschlag) and higher social security contributions borne by employers and employees alike, finished the spending spree of private and public households initiated by greatly increased governmental deficit spending. Compensatory and active manpower policies were largely funded by social security contributions, which jeopardized the price competitiveness of enterprises through increasing labour costs. This was the time when even organized employers became critical of the CDU-Liberal government, and when enterprises relocated production activities to Eastern countries that had also opened up and liberalized economic policies. In a short time, Germany became for a while a new 'sick man of Europe', with a high relative tax and contributions burden (more than 50\% relative to domestic product), high unemployment and low growth. ${ }^{10}$ In addition and at the same time, the German government had to share the financial burden of the Kuwait war against Iraq and financially support the Soviet Union when its own communist economic order collapsed. The unification party, of an exuberant spending spree, thus finished in a sullen hangover.

When the Social Democratic and Green coalition took over the Federal government in 1997, it inherited a conundrum of less competitive enterprises, labour costs overburdened with social security contributions and a number of further maladjustment problems. For a while, what was called the internet boom, the new foundations of internet-related small enterprises and productivity improvements due to internet communications in and across firms, brought back growth. In 2001, however, the internet boom and speculative expectations of an unending increase of asset values, in what was often exuberantly styled as a 'new

10 See Harding and Paterson (2000) for a discussion and critique. The authors in the volume show that the criticism of lacking innovativeness in industry was largely misguided. The criticism of institutional inertia was, for better or worse, heeded by the substantial that have taken place after about 1998 and above all 2003. No-one could accuse Germany of a lack of liberal reforms thereafter. These quickly finished the debate about Germany as a sick man of Europe. 
economic era', put an end to this boom. Ironically, it was the Social Democratic-Green government that had carried through in Germany most of the major liberal reforms of jointstock companies, stock markets and taxation of stock transactions, in the hope that this would improve growth for the duration and improve tax and contributions revenue in due course. This was no exception in Western Europe; Social Democratic governments were at the forefront of liberal reforms at the time, if only for the reason that they were in power and followed the imperial policy approach of deregulation, liberalization, reduction of public engagement in utility, transport and other public enterprises, and, most important, international financialization, the marketization and tradeability of all manner of assets, including assets consisting of tradeable liabilities, such as collateralized debt obligations.

Confronted with the consequences of both, the structural problems and state debt resulting from the unification process, and the collapse of the internet boom, Germany was approaching a financial collapse of the welfare state in the form it existed in 2002. The predicament was as dire as that, more than in comparable countries at the time. Whereas these also had to weather the storm of the internet crisis, they did not have to salvage a former communist economy on the basis of an assimilation of working conditions, economic welfare and public services, on a more or less equal footing with the capitalist West German economy, within a short period of time. After some to-and-fro of policy development, with and attempted pact for employment, the Social Democratic-Green government came up with an 'Agenda 2010' that boiled down to the partial dismantling of the welfare state (reduction of coverage and of entitlement levels and periods), mainly in unemployment insurance and welfare provisions but also in public health insurance and retirement benefits. In more classical terms, this amounted to the creation of a reserve army of labour even more massive than it already was because of unification. This also led to a severe crack in the relations that had tied the union movement to the Social Democratic Party and to a secession in this party leading to a new party which eventually finished up in 'the Left'. For our purposes here, the main consequence was a revitalization of the old-fashioned 'wage whip', i.e. the constraint to accept any work whatever the wage, or subsist on shrunk welfare entitlements. It is an irony that the main 'inventor' of these reforms, Peter Hartz, was as far from a neoliberal ideologue as one could get, as the personnel director of what is probably the most codetermined large joint-stock enterprise in Germany (VW), as the architect of a social compromise with regard to the reduction and flexibilization of working time in the firm to keep employment stable but also adapt it to fluctuating demand, and as a past IG Metall union officer with substantial experience in managing the steel industry crisis of the later 1970s, in his native Saarland. His personal background was as DQP as it could get, and the more vivid is he as the incarnation of a turnaround from within 'Modell Deutschland'. ${ }^{11}$

All this points to the option that emerged as the dominant one: It was not associated with the high road of DQP, but with swallowing the bitter pill of real wage reduction,

11 The name is also unfortunately associated with a scandal in VW, around the provision of prostitutes to himself and higher works council members. Moral outrage aside and trying to avoid hypocrisy, this is only what was to be expected in a co-determined enterprise, that employee representatives should be entitled to the same benefits as higher management, according to a principle of full parity. It is also not known or forgotten to what extent paid invitations to a brothel have formed part of working class culture, notably where work was also very physical, such as when a larger building site project was finished. 
notably in public services and services such as catering, cleaning, post, logistics, transport and health services. In internationally exposed industries, the cutback was not as severe in many places, but industrial relations were also marked by an institutional dismantling of arrangements that had become part of the wider DQP complex of affinities. Here we follow Baccaro and Howell (2017) who have provided an authoritative account which is not only succinct but also encompassing:

- A first tendency was to segment the value chain and decrease the vertical integration of enterprises, such that a number of production and service functions were relocated outside the focal enterprise into supply or service firms.

- This permitted not only greater managerial simplicity but also cost-cutting where wages and other conditions are concerned.

- A related cost-cutting motive was present in the use of foreign or migrant workers, employed in contract firms on the terms of their home country rather than the country of work, or somewhere in-between, and in any case below applicable collective agreements. The most vivid example is the success of German sausage and meat firms, resting on minimal wages for butchers recruited in Eastern Europe.

- A growing numbers of collective agreements allowed for exceptions (reductions of levels of provision) in specific firms, subject to negotiation with local bodies, usually works councils. Generically, this is often referred to as 'concessions bargaining', whereby management sought a reduction of levels of provision in return for not closing or shrinking a facility.

- Employers' associations have started to refrain from expelling firms that did not comply with a collective agreement.

- Collective bargaining coverage has been weakened, by both membership of unions and employers' association declining and weakening the power of both types of organization. This movement was triggered after union and association membership in East Germany immediately post-unification was very high but collapsed, with the collapse of privatized enterprises in East Germany.

- Confronted with a drastic increase in unemployment few years after unification, and with the partial dissolution of the welfare state by the 'Hartz' reforms after 2003 mentioned above, unions pursued a bargaining policy of maintaining employment levels by wage claim moderation.

All this boils down to striving for competitiveness on the basis of costs and selling price, and on the basis of profit margins allowed by costs rather than quality. The consequence has been an important contribution to the lowering of unit labour costs over the years, together with the more DQP-like contributions such as operating flexibility due to versatile and responsible labour and reductions of work-in-progress. Much as the decline in unit labour costs over the years is certainly not incompatible with DQP, it is probably safe to say that it has been more influenced by cost reductions than operating flexibility after 1990 .

There is another effect that contributed to enhancing the competitiveness of establishments in Germany: the introduction of the Euro as a currency in 2000. Much as the Deutschmark had stopped appreciating against other currencies after unification, the Euro put a more or less definite end to it and in the longer term, also because the value of the new currency was more influenced by national economies with a less positive balance of payments, slid back against the Dollar. Thus, in trade beyond the EU borders, German 
products and services became ever more competitive through the Euro alone. Baccaro and co-authors analysed the relation between export growth and the development of the 'real effective exchange rate' (REER), taking into account changes in prices; for Germany there has been a decline of the REER after unification and an appreciation before, more or less consistently (see the Comment by Baccaro that follows after this article, and the literature quoted there). This confirms the present analysis of the importance of unification for a number of things, also for the foreign trade balance and the growth model the economy has followed. It also shows that the currency revaluation-based stimulation of DQP that we had originally surmised in 1988, was turned around in 1990. Furthermore, the authors showed that exports grew more substantially in Germany, the more the REER declined. In other words, the pressure to enhance DQP became negative, or it did not follow our older statement any more.

In consequence there has been a more polemical economists' debate on the unfairness of Germany outcompeting other European countries by cost-cutting and low inflation in the Euro zone. The political irony, whatever one's political point of view, of all this is too tempting to avoid here. The Euro had not been desired by the public or politics in Germany, and many German economists had signed a petition considering it as unviable and a threat. The Euro was a political gift that Germany had to make, mainly to the French President and to the European Commission then led by Jacques Delors, to show that it cared for the unification of Europe and not only for the unification of Germany. It was a gift to allay fears that Germany could become nationalistic again. No-one could expect that the Euro would favour the German growth model established by 1990. No-one could, for that matter, expect that the Euro would favour a French or Italian growth model, either, because especially the latter depended on devaluations of the currency to restore competitiveness after uncontrolled price rises. In other words, the effect of the Euro did not surprise either its German or Italian opponents, but it very much took its proponents aback.

Who profits from the Euro was largely determined by the games that actors played in its consequence. Here lies the stark difference. In the South of Europe, the Euro was harnessed to drive up state debt because the interest rate for sovereign debt had become more advantageous under the Euro. It was not used as an opportunity to enhance competitiveness of firms in the South of Europe. In Germany, policies were exactly the opposite: Under the postunification pressure on the welfare state and the clear threats to the established growth model, actors 'conspired' to re-design value creation systems to become more competitive, generate employment, taxes and contributions, and enable a reduction of state debt. We say 'conspired' although no conspiracy in the literal sense is implied. But this is what the action amounted to, a tacit quasi-conspiracy that was explicit on the part of employers and the former government, not so much in the sitting government of the Social Democrats and Greens. It was also grudgingly uncontested by the unions, by wage restraint and compliance with many of the cost-cutting operations in industrial relations mentioned above. This was certainly not a hard-core German institutional 'model'. But it rested on a socio-institutional bedrock of working together that would have been unthinkable without the institutional foundation to DQP, mentioned by Streeck (1991) and discussed above. Here we see that the ensemble of institutions prevalent in a society have to be divided into at least types: proximate institutions that are specific and precise, and background institutions that reflect deeply rooted normative assumptions that assert themselves even when proximate institutions change (Whitley, 1992, p. 19). This institutional bedrock had proved its mettle in the 
industrial crises of the 1970s and 1980s. Now of course it took effect under different auspices, the threat of even more massive unemployment, which explained the relative compliance of the unions in a spirit of solidarity beyond their membership.

Within the wider complex of socio-economic institutions, a differentiation of change and continuity findings is required: Convergence towards liberal institutions was clearest in the corporate governance of joint-stock enterprises and the stock market, in the weakening of unions and decentralization of wage bargaining, and in the retrenchment of the welfare state. But there were also continuities, such as the preservation of codetermination-against political attacks from the liberal side-, the disappearance of the Nener Markt (a stock exchange for smaller and new firms), and the adherence to human resource policies seen to be conducive to export success (Jackson and Sorge, 2012). Our earlier elective affinities and complementarities were thus either dissolved or they became weaker.

Referring to the relative price inelasticity of demand for DQP products mentioned in our earlier writings, Baccaro and Howell (2017), see also the Comments by Baccaro that follows the present article, suggested that the declining REER for Germany showed a turn away from DQP. It was less DQP exports that explained German export success more recently but simple price competitiveness. The argument has some plausibility in so far as macro incentives were demonstrated to favour de-emphasis on DQP. However, the relation between declining REER and export growth was established at macro and sectoral levels, not at the firm level. An ecological fallacy is possible, but it may not be likely. On the other hand, the field in which German exports have grown above all in the last decade, is that of investment goods exported to China. Investment goods are, of course, a very DQP area indeed. They are hardly produced in large batches and often customized according to the requirements of buyers who are more professionally judicious than for consumer goods. Furthermore, a comparison of prices for comparable goods from manufacturers from different countries, we submit, would probably show that German products still fetch higher prices in return for a brand name and other qualitative considerations. It would also be interesting to compare product qualities attributed to competing makers from different countries. While we do not have representative comparative information, despite the recent VW scandal about manipulated emissions tests, it would be true to say that the quality image of German products still stands firm, not only in cars but in something as commonplace as household appliances such as washing machines or vacuum cleaners. Matched comparisons of German operations systems with those of other countries have regrettably become rare over the last decades, so that the evolution of operations systems in comparison is more difficult to trace. But what we can see in such a rare case of a more recent comparison, and in a 'new service industry' (call centres), between the USA and Germany, is: All the differences that we have become aware of, with regard to operations systems' organization, human resources and industrial relations, are exactly the way they have been before (Doellgast, 2012).

It is also clear that Germany has maintained its performance in the high price and quality segment of the motor car market, with such brands as Mercedes, BMW, Audi, Porsche, etc. At the end of the 1980s, Japanese makers set out to increase their market share in this segment, which had been negligible until then. Given the legendary reputation of the Japanese at the time, of cracking any market they were determined enough to attack, expectations were high. ${ }^{12}$ However, they never did increase their market share. The world market shares of the German high segment makers never declined. ${ }^{13}$ Our interpretation is that the operations systems performing in this segment have maintained their affinity with the engineering 
intensity and combination of routineness with non-routineness Germany has been distinctive for. DQP has apparently in principle been unchanging for Germany on this count. Also, the high price connotation has never changed for the German firms in comparison to others, and it does not appear to have been detrimental. ${ }^{14}$ We would also contend that Germanmade cars in the middle segment are most likely to be more expensive than their foreign rivals. This, of course, does not exclude that they profited from the REER development described above. What we probably see is a combination of relative cost-cutting with persisting price differentials, which constitutes another qualification of our initial concept.

Herrigel (2015) showed that German manufacturers unchangingly emphasize the quality of the product in company policies, whether it is in multinational enterprises (MNEs) also producing abroad, or in directly exporting firms. On balance, however, we grant that evidence does not point to any change in the direction of further customization of products. If anything, collection of information from firms would probably show that exporting relies on a combination of both price and quality sensitivity, and that stagnation or reduction of labour costs did play a part. This was certainly so in the case of Gardena mentioned above, in which concessions bargaining (reduction of wages) happened, in return for maintaining a production site in Germany. Many more examples could easily be adduced. However, the effect of relocation of activities of German MNEs to other countries is, as Herrigel (2015) showed, that activities remaining in Germany are more in research and development and in the non-routine functions in production (planning, production engineering, quality services, etc.). On balance, this amounts to an upgrading of competence in the German sites, within an increasingly complex distribution of functions in the value chain over sites and countries. This complexification of the value chain organization is, as the author argues, not merely a phenomenon of outsourcing motivated by cost-cutting but also of increasingly technical complexity, which is in turn related to policies of innovation and of augmenting quality.

Within German MNEs, the setting-up of foreign subsidiaries with functions beyond sales and service, i.e. in production or research and development, is shown to have increased substantially over time. Mittelstand companies have also often become multinational. Main motives are to manufacture (produce or develop) closer to distant markets, and save on both production and distribution costs. The cost-saving motive in the setting-up of foreign subsidiaries is obviously related to the one discussed above. Cost-saving rivals with being closer to a market, in the frequency and priority with which it is prevalent in enterprises. Generally, cost-saving is a more prevalent motive upstream in a focal enterprises; closeness to the market is more related to the downstream side; but cost-saving is a potent motive both downstream and upstream. But in a number of larger industries, the location and ownership of activities is often a very political decision, dependent on the 'micro politics' in any organization and the 'macro politics' involving business interests and the government

12 Chris Freeman, a leading scholar in the social science of technology, asked one of us at the time whether this might not spell the relative decline of the mentioned German manufacturers. The answer was: Not very likely. Now we know why.

13 See The Economist, June 7th, 2014, pp. 59-60.

14 This is reflected in the following anecdote from Germany: A new Lexus car owner is filling up on fuel at the local petrol station. A friend sees him with his new car, and calls out: 'Can't you afford a Mercedes, then?' 
(Dörrenbächer. and Geppert, 2011). This is particularly pertinent outside Europe and North America.

Now, whereas there had been a drive to set up subsidiaries abroad, in which costcutting has been the primary or secondary motive, the trend appears to have been reversed in the middle of the last decade, as Kinkel and Maloca (2009) showed. From then on, more enterprises have taken activities back to Germany and the rate of founding foreign subsidiaries has gone down. The motive of taking back activities, mainly from Central and Eastern Europe, was that initial expectations have not materialized, costs have gone up abroad and infrastructure in the widest sense (reliability of transport, government services and human resources provision) has posed problems. Enterprises thus moved back home for, again, combined motives relating to both costs and quality. Infrastructure in the widest sense was experienced as better in Germany and cost advantages of the foreign sites had shrunk; cost reductions in Germany that had taken place in the meantime must have played a role in this calculation. Again, we have the combined motives of labour costs and qualitative considerations rooted in corporatist institutions attached to DQP. And it is clear that the qualitative considerations also have an impact on the selling price of products. So, they have been important but they appear to be positively related to the the price sensitivity of demand for the product: Embeddedness in a German institutional infrastructure appears to have had a negative or neutral impact on the selling price: Of late, products and components do not appear any more to become cheaper by relocation to Eastern and Central Europe. While we had not considered price competitiveness as a part of DQP in our initial exposition, it does attest to the resilience of elements of the institutional DQP bedrock. This is something that critics of DQP theory who analysed the relation with the REER did not consider. It does not refute their argument entirely but shows that the picture is more complex and in need of nuances.

To summarize the present section, it we would say:

- As predicted, a combination of liberalization policies and unification shocks and responses in the period after 1990 led to socio-economic configurations different from those in the period 1972-1990.

- After an initial deficit-spending boom and growth, a continuation of DQP in the way it had become familiar had become economically and sociopolitically unviable.

- A main difference is the revitalization of price competitiveness, by cutbacks in social insurance benefits and government spending and on the basis of wage cuts and moderation, mainly after 2002 .

- Throughout policies to segment the organization of the value chain and relocate production abroad, an emphasis on product quality appears to have been unchanged, as was the increasing emphasis on directly exported investment goods.

- On the other hand, the earlier (1972-1990) tendency towards non-routine operations appears to have stopped or was even reversed.

- The period $1990+$ and above all $2002+$ is strangely to some extent more similar to the period 1945-1972, where price competitiveness through a stable currency and less inflation and more wage moderation than in competing countries is concerned. It is of course dissimilar since the welfare state was extended in the earlier period, whereas it was retrenched in the later period. 


\section{The most recent intermediate balance}

On the one hand, as the past summary indicates, Germany has become a different socioeconomy, different from what it had come to be until 1990 but also from what a hopeful interpretation of DQP suggested before 1990, never mind the partial liberalization in the 1980s which had, however, addressed the public and utilities sector more than manufacturing and related services. But comparatively, Germany has remained a dominant industrial economy, in which manufacturing and related services account more for value-added and employment than elsewhere, except from its own fringe of alpine countries. This comes out as the singularly important comparative feature in a long-term perspective.

The current picture of DQP is thus mixed. On the one hand, product quality as one important ingredient of DQP has retained its importance, both in investment goods and consumer durables. The international industrial division of labour, in MNEs and in directly exporting firms, which favoured domestic retention or expansion of indirect production ( $R \& D$, production planning and control, quality services, etc.) has meant some upgrading and non-routineness of work in the domestic economy, although there has also been a tendency of routinization in such functions. On the other hand, the conclusion imposes itself that taking activities in MNEs back to Germany from other countries, and the restoration of price competitiveness of domestic production, have arrested the increase of non-routineness. Yet, examples mentioned bring out that Germany appears more distinctive for dynamic combinations of routineness and non-routineness (large batch production and customized production) in the same enterprise and on the same site, and for incremental rather than radical movements along this dimension.

Any view of history is always a reinterpretation influenced by a current picture. It also sheds a light on the contextual conditions that have influenced a past interpretation. In this vein, we have to reinterpret and adapt our initial exposition of DQP in Germany, also in the light of our research after 1988 discussed above: Germany is not the country of 'hard-core' DQP, in the sense of price-inelastic, both quality and non-routineness centred manufacturing, more than elsewhere. But its version of DQP, while shading more into routine manufacturing, has become more encompassing and instituted across industries than elsewhere. It is wider than 'hard-core' DQP and by that token more encompassing and sustainable after a shock. This is our reinterpreted picture, resting as it does on our results with regard to operations systems just after our initial statements. Thus, changes in the characteristics of operations systems do not appear to constitute a major break after unification. While the emphasis on quality has been pervasive over longer periods of history after about 1880 , the non-routineness dimension shows a more ambivalent picture: It is the relative ambidexterity in the combination of routineness and non-routineness, and in shifting the emphasis in the same enterprise over time, which comes out as a defining characteristic for Germany. This continuity contributes to explaining developments after unification. Provocatively speaking, Germany has almost moved from a state of affairs in the end of the 1980 s back into a state of affairs in the post-war period, with wage moderation and a more stable currency permitting industrial development at home, along with a new combination of routine and non-routine manufacturing, as well as the producer services that have become more important.

So, Germany continued the DQP it had already had, with new products and engineering, organizational forms and human resources, in the product types it was already strong in: 
vehicles in high quality and customized market segments, and all manner of investment goods, to which aircraft and armaments had been added. But what distinguishes Germany from other countries except its own alpine fringe, is that it appears to care for the development of evolved production and linked operations systems. Whereas notably countries in the South of Europe just like the USA sought economic advantage, in the first decade after 2000 , in macroeconomic policies based on debt, Germany went back to the DQP it has had but to some extent uncoupled it from the institutions that we had initially construed as its supportive complementarities. This is something we did not expect but is conceptually very important. Politically, it is remarkable that Germany as one of the few countries to have profited from the Euro, had to be goaded into accepting the Euro in return for European approval of unification; conversely, a French-led European coalition for the Euro did after its introduction not succeed in making it a domestic success story, except initially when adoption of the Euro permitted more favourable interest rates for sovereign debt. The difference lies in the ability to arrange for a socio-economic setting, down to operations systems, which would make it a national success after the devastating consequences of the financial crisis had happened.

Baccaro and Pontussen, also following earlier comparative work, highlighted an instructive comparison of Germany and Sweden, in which Sweden comes out as having moved closer to a British profile of headquarters (marketing, finance), R\&D, consultancy and information technology functions, which would imply more non-routineness than in Germany, and exhibiting exports growth notably in such 'invisible' service exports (see the Comment by Baccaro that follows the present article). In their interpretation it therefore comes across as more DQP, whereas Germany has gone for tangible exports and incurred greater price competitiveness, which was seen to imply a move away from DQP although, as we showed above, a nuanced view is required. But the comparison with Sweden is particularly apposite. It is also a 'coordinated market economy' and was marked by fundamental changes over the years. Its past policies of wage equalization under union influence and Social Democratic government before 1990 had already led to a constant relocation of production activities abroad, such as IKEA furniture in Eastern Europe. Much of the staple product ranges (household equipment) of MNEs such as Electrolux and Ericsson, and of Volvo Cars, being routine operations with segmented operations systems, had also moved abroad. Sweden had been emptied of routine operations systems, of which it had had a great deal, even before it joined the European Communities, and despite the collapse of wage equalization by 1990, it continued doing so.

Sweden never had the ample share of independent Mittelstand companies that Germany has had. Sweden had an industrial structure dominated by large MNEs in large batch and mass production but was dominated by a high wage, high productivity and high income taxation coalition of few industrial oligopolies and the union movement. Before and after that collapsed, manufacturing enterprises relocated production abroad and MNEs acquired other companies in the continental EU. A prominent example of this is Vattenfall, a stateowned MNE that bought energy utilities in Germany and the Netherlands; another less prominent but instructive example is Gardena, a firm briefly discussed above, which finished up under Swedish ownership. This helps to visualize a complementarity between Sweden and Germany rooted in industrial differences: Swedish MNEs invested in German companies, thus providing these with corporate governance functions, in return for scaling down industrial production at home. Sweden was of course not alone in doing this. Since the later 1990s, Germany has received a lot of foreign investment into enterprises, from nearly everywhere. And this explains why wage-moderated Germany now exports a lot of tangible 
products, whereas highly taxed Sweden exports invisible services and makes a profit on wage-moderated German firms. The problem situation was of course quite different for Sweden and Germany: Sweden did not have to reunite with, say, Estonia, on a basis of assimilating wages and other conditions in a short time; the German context of massive unemployment and pressures on the welfare state was not present. Likewise, Sweden did not politically have to adopt the Euro. It did, though, more or less track the Euro instead of continuing its earlier devaluation policies. This helps to see why DQP, under very different macroeconomic and political auspices in Germany, has taken a different course. In the period after unification, Germany became the champion of wage assimilation but between East and West, and in practice this boiled down to real wage reduction or moderation in the West. Sweden on the other hand dropped wage equality and profited from wage differences across borders.

Whereas German DQP has come to be qualitatively different where firms, operations systems and the economics of business are concerned, the picture has come to be even more different with regard to the wider institutional corollaries of DQP mentioned by Streeck (1991). This was highlighted by the political economy and industrial relations literature summarized by Baccaro and Howell (2017). Tangible institutions changed form and meaning appreciably. Streeck (2016) summarized this for much of manufacturing and private services, but also for the public sector in the following way: The character of Konfliktpartnerschaft (partnership in conflict between the unions and the employers) changed from conflict without partnership in the post-war situation to partnership without conflict now. Yet, the heritage of partnership seems to be strong enough to permit continuity at an institutional meta level, and probably the major explanation is trade union responsibility with regard to labour and employment more widely, rather than particular interests in industries or occupations. But this did not occur without problems for the major union movement, as occupational unions (e.g. railway drivers, airline pilots and other aircrew) started to pursue their interests in separation and became more strike-prone.

In summary, through the combined effects of unification and international liberalization, Germany has become very distinct, not only compared to other large (post-)industrial countries but also in relation to another coordinated market economy such as Sweden. It has

- maintained the importance of quality-centred industries and markets,

- with an array of both export-oriented and multinational enterprises,

- that have maintained the characteristic blend of routine and non-routine operations,

- and profited from steadily improving terms of trade as well as wage moderation,

- whereas the institutional complementarities of DQP have to some extent been uncoupled,

- both with regard to DQP and among themselves.

\section{Conclusions}

Not only DQP and its institutional complementarities have changed over time but also our view of what DQP has meant in Germany. First, we hope to have shown that DQP in Germany, to some extent contrary to our own initial presentation, was not quite what it was suggested or thought to be. Upon a closer view, it has been a combination of, and a series of shifts between, routine and non-routine operations, but it has been focussed on quality not withstanding. And 1990 was a crucial year that changed the economic context of DQP. To cope with post-unification problems under liberal auspices, Germany gradually 
abandoned governmental deficit spending, retrenched the welfare state and went for wage moderation and enhancing the competitiveness of enterprises, on the basis of improving terms of trade and wage moderation. It also became attractive again, as a production location in competition with Central and Eastern Europe.

Throughout this development, DQP itself, as a concept of production, did qualitatively evolve but not change fundamentally from what it was in the 1980s. What did change was the economic setting, which did not require more 'hard-core' DQP but favoured the maintenance of non-routineness in DQP. What changed substantially, however, was the extent and the way DQP was interdependent with a number of institutions. Such complementarities were loosened, which we termed the decoupling of institutions between themselves and with regard to DQP. Thus, DQP still exists in Germany, and has become even more important a part of the policies set in place. But both its macroeconomic and institutional socioeconomic aspects have changed considerably. The most striking continuity with the past is that Germany has given more attention to the redesign of operations systems than other countries, and by that token to maintaining industrial production.

This diagnosis of what happened over time has one important implication for comparative socio-economics and political economy. What we learnt above all, beyond a more precise conceptualization of DQP, is that complementarities are less sustainable than they were thought to be in these fields. They may be much more specific to place and time and, hence, subject to long-running changes in world capitalism. First, DQP became more important with the deindustrialization of the old industrial world. As we showed, its evolution in Germany was then marked by the impact of further crises and how a country tried to resolve their problems. Our present discussion therefore has to be seen against the background of capitalism continuously producing conditions that imperil specific modes of production temporarily established, and reducing the capacity of governments to maintain social cohesion by discretionary spending (Streeck, 2013).

The decoupling of complementarities is, however, not theoretically unfamiliar. In organization theory, Orton and Weick (1990) had suggested that the decoupling of organizations was in fact a dialectical phenomenon, with two sides: As relations become loosened so that organizations become more autonomous, the inevitable cross-referencing of action across organizations leads to other interdependencies. By analogy, this also applies to institutions. Thus, relative compliance of unions may overall remain stable, although their power was weakened and the welfare state and industrial bargaining were retrenched. Also, DQP may remain in place but become interdependent with stagnating wages and stability of the currency, whereas it was previously interdependent with rising wages and appreciating currency values. As DQP changes form, so does its embeddedness in a set of economic and socioinstitutional conditions. In a longer perspective, its function of counteracting economic decline in an older industrial economy also remains the same, although the socio-economic contextuality of this counteraction changes from one crisis to another.

\section{References}

Baccaro, L. and Howell, C. (2017) European Industrial Relations: Trajectories of Transformation, Cambridge, Cambridge University Press.

Cox, J. C., and Kriegbaum, H. (1980) Growth, Innovation and Employment. An Anglo-German Comparison, London, Anglo-German Foundation for the Study of Industrial Society. 
DiMaggio, P. J. and Powell, W. W. (1991) The New Institutionalism in Organizational Analysis, Chicago, University of Chicago Press.

Doellgast, V. (2012) Disintegrating Democracy at Work. Labor Unions and the Future of Good Jobs in the Service Economy, Ithaca, NY, ILR Press.

Dörrenbächer, C. and Geppert, M. (eds) (2011) Politics and Power in the Multinational Corporation. The Role of Institutions, Interests and Identities, Cambridge, Cambridge University Press.

Harding, R. and Paterson, W. E. (eds) (2000) The Future of the German Economy. An End to the Miracle? Manchester, UK, and New York, Manchester University Press.

Herrigel, G. (2015) 'Globalization and the German Industrial Production Model', Journal of Labour Market Research, 48, 133-149.

Hollingsworth, J. R. (1991) 'The Logic of Coordinating American Manufacturing Sectors'. In Campbell, J. L., Hollingsworth, J. R. and Lindberg, L. N. (eds) Governance of the American Economy. Cambridge, Cambridge University Press, pp. 35-73.

Jackson, G., and Sorge, A. (2012) 'The Trajectory of Institutional Change in Germany, 1979-2009', Journal of European Public Policy, 19, 1146-1167.

Kinkel, S., and Maloca, S., (2009) Produktionsverlagerung und Rückverlagerung in Zeiten der Krise. Karsruhe, Fraunhoferinstitut für Systemtechnik und Innovationsforschung, Modernisierung der Produktion, Ausgabe 52.

Maurice, M. and Sorge, A. (eds) (2000) Embedding Organizations. Societal Analysis of Actors, Organizations and Socio-Economic Context, Amsterdam, John Benjamins.

Orton, D., and Weick, K. (1990) 'Loosely Coupled Systems. A Reconceptualization', Administrative Science Quarterly, 15, 203-223.

Perrow, C. (1970) Organizational Analysis. A Sociological View, London, Tavistock Publications.

Porter, M. (1980) Competitive Strategy. Techniques for Analyzing Industries and Competitors, New York, The Free Press.

Selznick, P. (1996) 'Institutionalism "Old” and "New"', Administrative Science Quarterly, 41, 270-277.

Sorge, A., Campbell, A., and Warner, M. (1989) Microelectronic Product Applications in Great Britain and West Germany: Strategies, Competence and Training. Aldershot, Gower Press.

Sorge, A., Hartmann, G., Warner, M. and Nicholas, I. (1983) Microelectronics and Manpower in Manufacturing: Application of Computer Numerical Control in Great Britain and West Germany, Aldershot, Gower Press.

Sorge, A., and Maurice, M. (1990) 'The Societal Effect in Strategies and Competitiveness of Machine Tool Manufacturers in France and West Germany', International Journal of Human Resource Management, 1, 141-172.

Sorge, A., and Streeck, W. (1988) 'Industrial Relations and Technical Change: The Case for an Extended Perspective'. In Hyman, R. and Streeck, W. (eds) New Technology and Industrial Relations, Oxford, Blackwell, pp. 19-44.

Streeck, W. (2016) 'Von Konflikt ohne Partnerschaft zu Partnerschaft ohne Konflikt: Industrielle Beziehungen in Deutschland', Industrielle Beziehungen, 23, 47-60.

Streeck, W. (1991) 'On the Institutional Conditions of Diversified Quality Production'. In Matzner, E. and Streeck, W. (eds) Beyond Keynesianism: The Socio-Economics of Production and Full Employment, Aldershot, Edward Elgar, pp. 21-61.

Trist, E. (1981) The Evolution of Socio-Technical Systems. A Conceptual Framework and an Action Research Program, Toronto, Ontario Quality of Working Life Centre, Occasional Paper no. 2.

Whitley, R. (1992) European Business Systems: Firms and Markets in Their National Contexts, London, Sage. 